\title{
Uma boaventurança para Belém do Pará
}

\author{
Silvia Nogueira Chaves
}

\author{
Um lugar deve existir \\ Uma espécie de bazar \\ Onde os sonhos extraviados \\ Vão parar \\ Chico Buarque de Holanda
}

T Tá de haver algum lugar uma espécie de bazar onde sonhos e $\perp$ Lemoções extraviadas vão parar. Cartas são datadas, sonhos e emoções não. Encontrei essa carta na "posta restante" de meu computador, num velho arquivo de missivas endereçadas e nunca expedidas. Foi dali que a resgatei deparando-me com a vivacidade da emoção sentida por ocasião da conferência de Boaventura de Souza Santos em Belém do Pará. Conferência proferida ironicamente na véspera das comemorações de mais um ano de independência do Brasil da monarquia portuguesa. Nove anos se passaram desde aquela ensolarada tarde de setembro e do crepúsculo que a seguiu. Hoje já não são as ideias de Boaventura Santos que inspiram minhas pesquisas acadêmicas, mas a elas permaneço grata por sustentarem-me em uma de minhas muitas travessias.

Prezado Professor,

Já faz algum tempo que tomei a decisão de não deixar passar a oportunidade de expressar pensamentos e sentimentos que as pessoas me provocam e despertam. É com esse propósito que escrevo agora. 
Ontem tive o privilégio de ouvi-lo falar à beira do Rio Guamá na Universidade Federal do Pará. Protegida pela penumbra do ocaso emocionei-me até as lágrimas. Ouvi-lo falar de solidariedade, de respeito e afeto, num ambiente em que essas palavras às vezes não têm guarida, renova em mim a esperança que me mantém caminhando.

Houve um momento em minha trajetória, quando estava em processo de doutoramento, que a vida acadêmica perdeu o sentido. Naquela ocasião deparava-me com os dois acontecimentos cruciais da existência humana, o nascimento e a morte. Diante desses momentos polares, desses dois lados da mesma viagem, como diz Fernando Brant, as "coisas da Terra" ficaram muito pequenas.

Ali eu pensei em desistir da academia, lugar que abriga e atiça orgulho e vaidade, sentimentos que passei a sentir necessidade de expurgar. Inúmeras vezes perguntei-me que contribuição poderia dar para o mundo alimentando meu ego, pleno de razão e esvaziado de sentimentos. Foi lendo suas palavras que consegui atribuir outro significado ao meio acadêmico e tomei a decisão de cá permanecer.

Entendi, por meio da leitura de suas obras, que se quisesse falar de outros valores dentro da universidade e ser ouvida pelos meus pares eu precisava ser um deles, se eu quisesse ser uma voz dissonante precisava saber me expressar na "lingua dominante", ainda que eu falasse contra ela. Mas, sobretudo, entendi que se eu quisesse introduzir, naquele meio, outros valores eu precisava vivê-los em minhas ações.

Não o conheço para além de suas idéias. Como bem nos disse ontem, mais do que nossas idéias somos nossas crenças. Assim, épossivel que a contradição o habite, como humano que é. Mas para mim isso não importa, pois foram suas idéias que reforçaram e renovaram minhas crenças.

Ao ouvi-lo falar ontem me invadia um sentimento de responsabilidade que às vezes conseguimos adormecer. Como creio em múltiplas 
existências, fiquei pensando que a mensagem com a qual nos brindou à beira do rio relembrava-nos compromissos assumidos outrora de nos empenharmos na construção de um mundo melhor. Compromisso que talvez tenhamos assumido coletivamente, como humanidade, e que as ilusões do imediatismo, no qual estamos todos mergulhados, têm nos feito esquecer.

Obrigada por vir nos relembrar de fazer a nossa parte e, particularmente, por sempre renovar em mim a esperança. Não é sem motivo que seu nome é BOAVENTURA!

Sílvia Chaves.

Belém, 7 de setembro de 2006. 